\title{
Recent studies on particulate reinforced AZ91 magnesium composites fabricated by stir casting - a review
}

\author{
Anil Kumar MATTA, Naga Sai Suman KOKA, Sameer Kumar DEVARAKONDA
}

DOI: 10.30464/jmee.2020.4.2.115

Cite this article as:

Matta A. K., KOKA N. S. S., DEVARAKONDA S. K. Recent studies on particulate reinforced AZ91 magnesium composites fabricated by stir casting - a review. Journal of Mechanical and Energy Engineering, Vol. 4(44), No. 2, 2020, pp. 115-126.

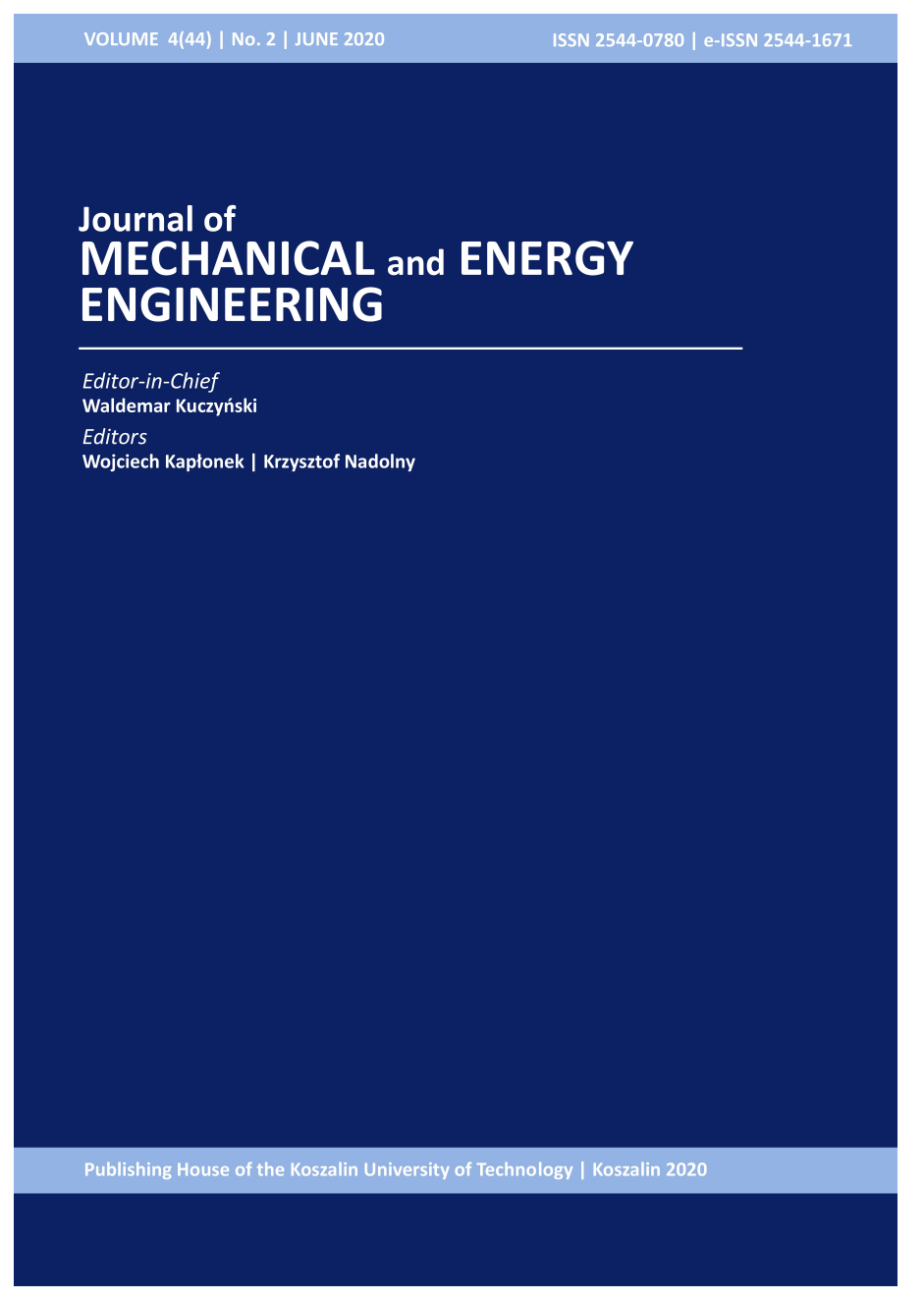

Journal of Mechanical and Energy Engineering

Website: jmee.tu.koszalin.pl

ISSN (Print): 2544-0780

ISSN (Online): 2544-1671

Volume: $4(44)$

Number: 2

Year: 2020

Pages: 115-126

Article Info:

Received 4 May 2020

Accepted 11 June 2020

\section{Open Access}

This article is distributed under the terms of the Creative Commons Attribution 4.0 (CC BY 4.0) International License (http://creativecommons.org/licenses/by/4.0/), which permits unrestricted use, distribution, and reproduction in any medium, provided you give appropriate credit to the original author(s) and the source, provide a link to the Creative Commons license, and indicate if changes were made. 


\title{
RECENT STUDIES ON PARTICULATE REINFORCED AZ91 MAGNESIUM COMPOSITES FABRICATED BY STIR CASTING - A REVIEW
}

\author{
Anil Kumar MATTA ${ }^{1 *}$, Naga Sai Suman KOKA², Sameer Kumar DEVARAKONDA ${ }^{3}$ \\ ${ }^{1 *}$ Department of Mechanical Engineering, Andhra University College of Engineering, Visakhapatnam, \\ Andhra Pradesh, India, e-mail: anilkumarmphd@gmail.com \\ ${ }^{2}$ Department of Mechanical Engineering, Andhra University College of Engineering, \\ Visakhapatnam, Andhra Pradesh, India \\ ${ }^{3}$ Department of Mechanical Engineering, Bapatla Engineering College, Bapatla, Andhra Pradesh, India
}

(Received 4 May 2020, Accepted 11 June 2020)

\begin{abstract}
Magnesium Metal Matrix Composites (Mg MMC) have been the focus of consideration by many researchers for the past few years. Many applications of Mg MMCs were evolved in less span of time in the automotive and aerospace sector to capture the benefit of high strength to weight ratio along with improved corrosion resistance. However, the performance of these materials in critical conditions is significantly influenced by several factors including the fabrication methods used for processing the composites. Most of the papers addressed all the manufacturing strategies of $\mathrm{Mg}$ MMC but no paper was recognized as a dedicated source for magnesium composites prepared through STIR casting process. Since STIR casting is the least expensive and most common process in the preparation of composites, this paper reviews particulate based Mg MMCs fabricated with STIR casting technology. AZ91 series alloys are considered as the matrix material while the effect of different particle reinforcements, sizes, weight fractions on mechanical and tribological responses are elaborated in support with micro structural examinations. Technical difficulties and latest innovations happened during the last decade in making Mg MMCs as high performance material are also presented.
\end{abstract}

Keywords: AZ91, ceramics, metal matrix composites, magnesium composites, particle reinforcement, stir casting

\section{INTRODUCTION}

Magnesium is the lightest metal with plenty of availability in the earth crust. Its density is $35 \%$ lesser than aluminum and it is $78 \%$ when compared to steel. Therefore, magnesium is selected as one of the alternate to steel and aluminum in many parts of an automobile and aerospace applications to promote fuel competence and to mitigate $\mathrm{CO}_{2}$ emissions [1-3]. But, the pure form magnesium cannot be used directly in typical applications as it is very sensitive. This behavior restricted the magnesium in the further usage of high end products. Thus, to make available with good strength, corrosion resistance and formability, magnesium is commonly alloyed with some other elements [4,5].
Magnesium alloys are classified into two groups namely wrought alloys and cast alloys. Many researchers conducted experiments to bring the detailed potentialities and applications of these alloys [4-8]. The mechanical properties of magnesium wrought alloys are established to be better than cast alloys but the research growth is limited as it involves high production costs and limited formability at normal operating temperatures [7]. Hence, casting is the convenient process in handling the magnesium alloys for commercial applications.

The most renowned magnesium alloys are $A Z$ series (Mg-Aluminum-Zinc) alloys. These alloying elements enhances the fluidity of casting to provide maximum possible strength to the prepared product. Though AZ alloys possess good tensile and moderate yield strength at normal temperature, the performance 
of these alloys at higher temperatures i.e. $>125^{\circ} \mathrm{C}$ is limited [8]. To resolve this, reinforcements are added to magnesium alloys and the materials are commonly called as Mg MMCs. These materials can have improved high specific strength, stiffness, creep, damping, wear and fatigue properties than pure magnesium or magnesium alloys. These composites made their mark in all segments of an automotive and aviation industries and emerged as the materials of future.

The composites are mainly characterized by the nature of reinforcement. These reinforcements may be particles, fibers, whiskers... etc. D.J. Lloyd [9] presented a detailed explanation on particulate reinforced aluminum and magnesium composites with an emphasis on manufacturing methods and reactivity. It is further noticed from the Lloyd's work that particle reinforced Mg MMCs induce higher elastic modulus, strength and wear resistance with low cost of fabrication. Abhijit Dey et al. [10] reviewed various categories of particle reinforcements that are commonly introduced into magnesium and their alloys by clearly highlighting the advantages and disadvantages. Some novel contributions in the area of $\mathrm{Mg}$ MMCs are also happened in the recent years to achieve the greater yield in view of mechanical and tribological properties [1115]. The number of works on Mg MMCs are keep on increasing and the same trend is expected to continue in the near future with different magnesium matrix alloys, reinforcement materials, fabrication methods, and innovations carried to achieve the desired properties. Therefore, this review paper addresses selective survey of particle reinforced AZ91 magnesium composites fabricated through STIR casting process from fundamentals to research happened particularly during the past decade.

\section{FUNDAMENTALS}

\subsection{AZ91 Magnesium alloys}

The name AZ series magnesium alloys is ascribed because of the alloying elements Aluminum(A) and Zinc ( $\mathrm{Z}$ ). The addition of aluminum to magnesium promotes hardness and castability while zinc improves strength without reducing $\%$ of elongation i.e. ductility [5]. Among various formulations of AZ series alloys, AZ91 alloys are popular and the number of articles publishing with AZ91 are mounting day by day [3]. Small variations in alloying elemental percentages made five sub classifications in AZ91 i.e. AZ91A, B, $\mathrm{C}, \mathrm{D}$, and $\mathrm{E}$ to make it ready for different applications. The composition of AZ91alloys are given in Table 1 .

AZ91A, AZ91B and AZ91D are die casting alloys among which AZ91A, B are used when the resistance to corrosion is not very much significant while AZ91D is high purity alloy with good sea water and atmospheric corrosion resistance. AZ91C and AZ91E are sand, investment, and permanent mould casting alloys [17].
Tab. 1. Different types of AZ91 alloys and their Chemical composition [16]

\begin{tabular}{cccccc}
\hline Type & AZ91A & AZ91B & AZ91C & AZ91D & AZ91E \\
\hline \multirow{2}{*}{$\mathrm{Al}$} & $8.3-9.7$ & $8.3-9.7$ & $8.1-9.3$ & $8.3-9.7$ & $8.1-9.3$ \\
\hline $\mathrm{Zn}$ & $0.35-1$ & $0.35-1$ & $0.4-1$ & $0.35-1$ & $0.4-1$ \\
\hline $\mathrm{Mn}$ & 0.13 & 0.13 & 0.13 & 0.15 & $0.17-$ \\
$\min$ & $\min$ & $\min$ & $\min$ & 0.35 \\
\hline \multirow{2}{*}{$\mathrm{Cu}$} & 0.10 & 0.35 & 0.10 & 0.030 & 0.015 \\
$\max$ & $\max$ & $\max$ & $\max$ & $\max$ \\
\hline \multirow{2}{*}{$\mathrm{Si}$} & 0.50 & 0.50 & 0.30 & 0.10 & $\begin{array}{c}0.20 \\
\max \end{array}$ \\
\hline \multirow{2}{*}{$\mathrm{Fe}$} & -- & -- & -- & $\begin{array}{c}0.005 \\
\max \end{array}$ & $\begin{array}{c}0.005 \\
\max \end{array}$ \\
\hline \multirow{2}{*}{$\mathrm{Ni}$} & 0.03 & $\begin{array}{c}0.03 \\
\max \end{array}$ & $\begin{array}{c}0.01 \\
\max \end{array}$ & $\begin{array}{c}0.002 \\
\max \end{array}$ & $\begin{array}{c}0.0010 \\
\max \end{array}$ \\
\hline $\mathrm{Mg}$ & Balance & Balance & Balance & Balance & \begin{tabular}{c} 
Balance \\
\hline
\end{tabular}
\end{tabular}

The restrictions on $\mathrm{Ni}, \mathrm{Fe}$ alloying elements makes AZ91E an exceptional corrosion resistance material among all AZ91 series alloys (Fig. 1). AZ91E and AZ91C can be welded with a stress relief while AZ91 A, AZ91B, AZ91D are not suitable for welding $[4,16]$.

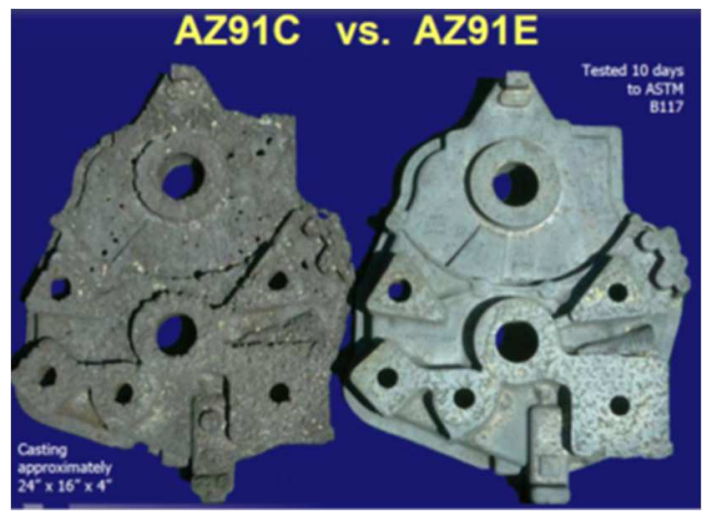

Fig. 1. Corrosion comparison of AZ91C and AZ91E [18]

\subsection{Ceramic particles}

Most of the ceramic particles are available in the form of oxides (e.g., $\mathrm{Al} 2 \mathrm{O} 3, \mathrm{SiO} 2, \mathrm{MgO}$ ), borides, carbides (e.g., SiC, B4C and TiC), nitrides (e.g., Si3N4, AlN) and elemental materials (e.g., C, Si). Table 2 indicates some properties of ceramic particle reinforcements. These ceramic particles are often chemically reacted with the matrix material and/ or totally transformed into a new phase due to which the properties of the composite were significantly altered [7].

D.J. Lloyd [9] mentioned that the (i) application (ii) method of manufacturing the composites and (iii) cost of reinforcement are the pivoted points in the careful selection of reinforcement to prepare MMCs. However, homogeneous scattering of ceramic particles in the matrix and chemical kinetics between matrix and reinforcement also play a predominant role in exhibiting the characteristics of the composite. 
Tab. 2. Few particle reinforcements and their properties [7]

\begin{tabular}{|c|c|c|c|c|c|c|c|}
\hline Particle Name & $-\mathrm{SiC}$ & $\mathrm{B}_{4} \mathrm{C}$ & $\mathrm{Al}_{2} \mathrm{O}_{3}$ & $\mathrm{BN}$ & AlN & $\mathrm{TiB}_{2}$ & $\mathrm{TiC}$ \\
\hline \multicolumn{8}{|l|}{ Properties } \\
\hline Crystal Type & Hex. & Rhomb. & Hex. & Hex. & Hex. & Hex. & $\mathrm{Cub}$ \\
\hline $\begin{array}{l}\text { Density } \\
{\left[\mathrm{g} \mathrm{cm}^{-3]}\right.}\end{array}$ & 3.21 & 2.5 & 3.9 & 2.25 & 3.26 & 4.51 & 4.9 \\
\hline $\begin{array}{l}\text { Coefficient of Thermal } \\
\text { Expansion }\left[10^{-6} \mathrm{~K}^{-1}\right]\end{array}$ & 4.7 & 5.0 & 3.6 & $0.8-7.5$ & 5.5 & $4.5-6.5$ & 7.4 \\
\hline $\begin{array}{l}\text { Heat Conductivity } \\
{\left[\mathrm{W} \mathrm{m}^{-1} \mathrm{~K}^{-1}\right]}\end{array}$ & 40 & 29 & 25 & 25 & 10 & 27 & 29 \\
\hline $\begin{array}{l}\text { Elastic Modulus } \\
\text { [GPa] }\end{array}$ & 480 & 450 & 410 & 90 & 350 & 370 & 320 \\
\hline
\end{tabular}

\subsection{STIR casting process}

STIR casting is one of the simple, vital and promising process in the manufacturing of Mg MMCs. In STIR casting, the reinforcement particles are introduced to molten metal and distributed by mechanical stirring mostly with an automatic stirrer. In case of magnesium composites, melting and stirring was done in an inert gas atmosphere to protect the melt from atmosphere. Schematic diagram of stir casting is represented in Figure $2 \mathrm{a}-\mathrm{b}$. STIR casting process can accommodate higher volume fractions without any damage to the reinforcement. However, the uniform distribution of reinforcement and the wettability between reinforcement and matrix are the main challenges in the preparation of composite to exhibit the desired properties $[9,11,20]$. Various strategies are adopted by the researchers to address this problem and are cited in the corresponding sections of the paper.

\section{PARTICLE REINFORCED AZ91 MAGNESIUM METAL MATRIX COMPOSITES}

Since careful selection of reinforcement will achieve the desired proprieties, the particle reinforced MMCs have arisen as vital materials as these always possess isotropic characteristics because of homogenous distribution. This section reviews various works carried with AZ91 based ceramic particle reinforced composites manufactured through STIR casting method.

\subsection{Silicon Carbide (SiC)}

The addition of Silicon Carbide particles $\left(\mathrm{SiC}_{\mathrm{p}}\right)$ will improve high stiffness, tensile elastic modulus, high temperature tolerance, corrosion and wear resistance [9-12,14].

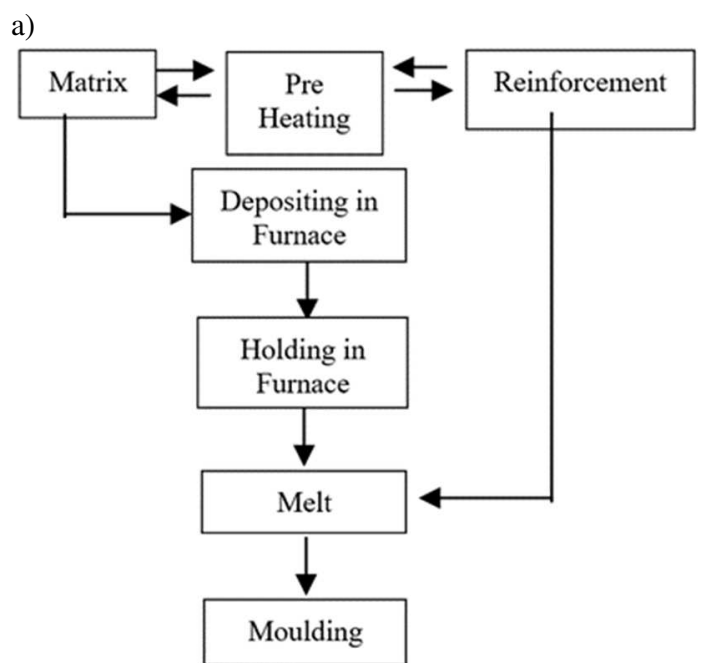

b)

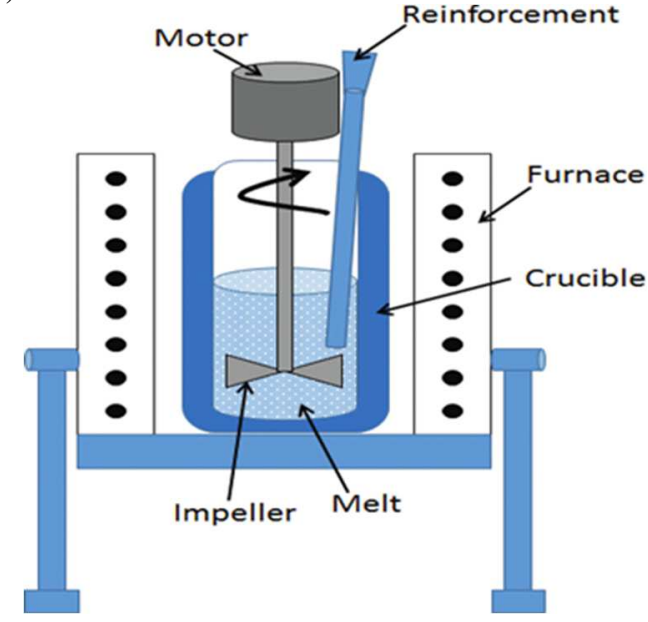

Fig. 2. STIR casting: a) procedure, b) setup in the preparation of composites [19] 
P. Poddar et al. [21] fabricated SiCp reinforced $\mathrm{Mg}$ and AZ91D composites by STIR casting technique with a vol. fraction $15 \%$ and with an average particle size of $15 \mu \mathrm{m}$ and $150 \mu \mathrm{m}$. Homogeneous dispersion of $\mathrm{SiC}$ particulates in AZ91D alloy is observed. An improvement in hardness and tensile modulus compared to monolithic alloy AZ91D is noticed due to the grain refinement because of SiCp addition. AZ91D alloy exhibited ductile type of fracture, whereas the fracture surfaces of AZ91D/ SiCp composites shown particulate breakage and SiC- AZ91D matrix debonding. X. J. Wang [22] conducted various interfacial studies on AZ91/SiC composites and stated that the interface between particle and matrix play significant role in the transition of loads. The particle/matrix interfaces can be categorized into three phases according to their morphological characteristics (Fig. 3). Detailed chemical reactions along with Interfacial Reaction Products (IRPs) at the particle/matrix interface are presented in support with EDAX spectroscopy. $\mathrm{A} 14 \mathrm{C} 3, \mathrm{MgO}, \mathrm{Mg} 2 \mathrm{Si}$, Mg17Al12 and Al8Mn5 may occur at particle/matrix interface because of $\mathrm{SiC}$ addition to AZ91 due to which significant change in the properties are happen. Interface Type I is reported as an ideal condition for the enhancement of mechanical properties.

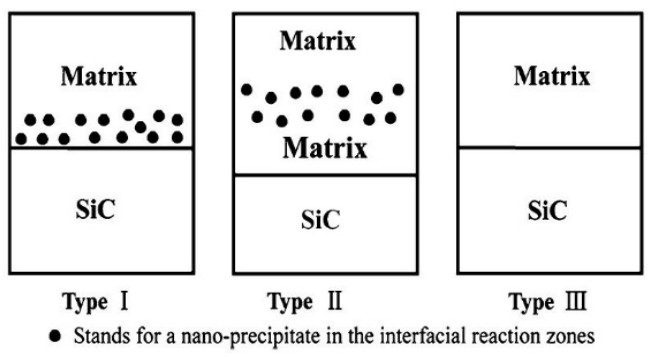

Fig. 3. Representation of interfaces according to morphological features [22]

A. Kandil [23] pre-treated the $\mathrm{SiC}$ particulates (average size $50 \mu \mathrm{m}$ ) over the temperature 1100 0c and induced into AZ91 matrix. Except AZ91 intermetallic compound $\mathrm{Mg} 17 \mathrm{Al12}$, no additional reaction takes place between the oxidized $\mathrm{SiC}$ and the molten AZ91 due to $\mathrm{SiO} 2$ formation on the surface of $\mathrm{SiC}$ because of pre-treatment. The oxidized $\mathrm{SiC}$ particles are also provided improved mechanical performance due to grain refinement while examinations of the fracture surface shown fine dimples and particle cracking regions as similar to earlier results [21]. Sujayakumar Prasanth et al. [24] produced AZ91 composites with different weight percentages of $\mathrm{SiCp}$ i.e. $5,10,15,20$, and $25 \%$ with a mean particle size of $23 \mu \mathrm{m}$. The electrical conductivity and the coefficient of thermal expansion values of AZ91/SiCp composites found to be decreased with increase in wt.\% of SiCp while the hardness and the compressive strengths are increased with an increase in reinforcement. Later, the sliding behavior of these composites was reported with regards to wear rate, wear resistance and coefficient of friction. The wear rate of the composite is found to be decreased and wear resistance is increased as such $\mathrm{SiCp}$ reinforcement induces the hardness and strength to soft and ductile AZ91 magnesium matrix due to oxidation, delamination, and abrasion wear mechanisms [25]. K. K. Ajith Kumar [26] and Abhilash viswanath [27] also evaluated physical, mechanical, tribological and creep phenomenon of stir cast AZ91/SiCp composites.

Though the properties of AZ91/ micro SiCp composites are encouraging, it always known fact that reduction in particle size can cause better grain refinement. However, thermal stability, wettability and uniform distribution of nano sized particles is major issue. Therefore, a modification in the STIR casting process such as Rheo-casting [28], Two step STIR casting [29] and STIR casting supported with ultrasonic vibration [15] have been implemented for the homogeneous distribution of nano SiCp in AZ91 Alloy. Zhao-hui et al. [30] fabricated AZ91 / nano SiCp based composites through ultrasonic method of dispersion in $0.1 \%, 0.3 \%$, and $0.5 \%$ mass fractions. The microscopical characterization of these composites confirmed the uniform distribution of particles in the AZ91 magnesium alloy with aid of ultrasonic vibration. SiCp nano particles promoted heterogeneous nucleation of $\alpha-\mathrm{Mg}$ so that composite grains were refined and the mechanical properties increased dramatically relative to monolithic matrix alloy. Anil Kumar et al. [33] developed low cost vacuum based stir casting machine and conducted studies on AZ91/SiC composite with or without flux. Vacuum stirring process without flux yielded good properties because of low porosity values than flux assisted composites. A. Asgari et al. [34] developed composites with SiCp and AZ91 scrap as matrix. The yield strength of the composite was enhanced by 62.7 percent while toughness was improved by 46 per cent relative to the AZ91 magnesium alloy. The findings once again emphasized the recyclable advantage of magnesium by converting magnesium waste into successful product. Manoj Gupta et al. [5] reported the properties of $\mathrm{SiC}$ based $\mathrm{AZ}$ composites with various particle sizes and with different methods. Mechanical properties of some of the SiCp based AZ91 MMCs processed through stir casting procedures are mentioned in Table 3. 
Tab. 3. Mechanical properties of SiC reinforced AZ91 Composites

\begin{tabular}{|c|c|c|c|c|c|c|c|c|c|}
\hline Materials & $\begin{array}{l}\text { Size of } \\
\mathrm{SiC}_{\mathrm{p}}\end{array}$ & $\begin{array}{l}\text { Vol } \\
\%\end{array}$ & Method & Hardness & $\begin{array}{l}\text { UTS } \\
\text { in } \\
\mathrm{MPa} \\
\end{array}$ & $\begin{array}{c}\text { YTS } \\
(0.2 \%) \text { in } \\
\mathrm{MPa} \\
\end{array}$ & $\begin{array}{c}\% \text { of } \\
\text { Elongation }\end{array}$ & $\begin{array}{l}\text { UCS } \\
\text { in } \\
\mathrm{MPa} \\
\end{array}$ & Ref \\
\hline AZ91D & -- & -- & \multirow{3}{*}{$\begin{array}{l}\text { STIR casting } \\
\text { as cast } \\
\text { condition }\end{array}$} & $\begin{array}{c}77.0 \pm 0.9 \\
\text { VHN }(50 \mathrm{~g})\end{array}$ & -- & -- & -- & -- & \multirow{5}{*}{ [21] } \\
\hline \multirow{4}{*}{$\begin{array}{c}\text { AZ91D } \\
+ \\
\mathrm{SiC}\end{array}$} & $150 \mu \mathrm{m}$ & 15 & & $\begin{array}{c}81.4 \pm 1 \mathrm{VHN} \\
(50 \mathrm{~g}) \\
\end{array}$ & -- & -- & -- & -- & \\
\hline & $15 \mu \mathrm{m}$ & 15 & & $\begin{array}{c}86.6 \pm 1.5 \\
\text { VHN }(50 \mathrm{~g})\end{array}$ & -- & -- & -- & -- & \\
\hline & $150 \mu \mathrm{m}$ & 15 & \multirow{2}{*}{$\begin{array}{l}\text { STIR casting } \\
\text { T4 condition }\end{array}$} & $\begin{array}{c}82.2 \pm 1.2 \\
\text { VHN }(50 \mathrm{~g}) \\
\end{array}$ & $195 \pm 2$ & $\begin{array}{l}122 \\
\pm 3 \\
\end{array}$ & $\begin{array}{c}0.9 \\
\pm 0.1 \\
\end{array}$ & -- & \\
\hline & $15 \mu \mathrm{m}$ & 15 & & $\begin{array}{c}87.3 \pm 1.1 \\
\text { VHN }(50 \mathrm{~g}) \\
\end{array}$ & $204 \pm 3$ & $\begin{array}{l}134 \\
\pm 2 \\
\end{array}$ & $\begin{array}{c}1.2 \\
\pm 0.1 \\
\end{array}$ & -- & \\
\hline \multirow{6}{*}{$\begin{array}{c}\mathrm{AZ} 91 \\
+ \\
\mathrm{SiC}\end{array}$} & \multirow{6}{*}{$\sim 23 \mu \mathrm{m}$} & 0 & \multirow{6}{*}{$\begin{array}{l}\text { STIR } \\
\text { casting }\end{array}$} & $63 \mathrm{BHN}$ & 187 & 92 & 2.8 & 310 & \multirow{6}{*}{ [24-27] } \\
\hline & & 5 & & $82 \mathrm{BHN}$ & 184 & 119 & 1.1 & 317 & \\
\hline & & 10 & & $86 \mathrm{BHN}$ & 182 & 115 & 0.8 & 334 & \\
\hline & & 15 & & $90 \mathrm{BHN}$ & 182 & 113 & 0.68 & 344 & \\
\hline & & 20 & & $92 \mathrm{BHN}$ & 184 & 119 & 0.6 & 353 & \\
\hline & & 25 & & $97 \mathrm{BHN}$ & 184 & 123 & 0.48 & 364 & \\
\hline AZ91D & -- & -- & \multirow{3}{*}{$\begin{array}{l}\text { Rheo casting } \\
\text { as cast } \\
\text { condition }\end{array}$} & $\begin{array}{c}62 \mathrm{VHN} \\
(0.5 \mathrm{~N}) \\
\end{array}$ & -- & -- & -- & -- & \multirow{5}{*}{ [28] } \\
\hline \multirow{4}{*}{$\begin{array}{c}\text { AZ91D } \\
+ \\
\mathrm{SiC}\end{array}$} & $150 \mu \mathrm{m}$ & 15 & & $\begin{array}{c}75 \mathrm{VHN} \\
(0.5 \mathrm{~N})\end{array}$ & -- & -- & -- & -- & \\
\hline & $15 \mu \mathrm{m}$ & 15 & & $\begin{array}{c}78 \mathrm{VHN} \\
(0.5 \mathrm{~N}) \\
\end{array}$ & -- & -- & -- & -- & \\
\hline & $150 \mu \mathrm{m}$ & 15 & \multirow{2}{*}{$\begin{array}{l}\text { Rheo casting } \\
\text { T4 condition }\end{array}$} & $\begin{array}{c}77 \mathrm{VHN} \\
(0.5 \mathrm{~N}) \\
\end{array}$ & 169 & 155 & 1.6 & -- & \\
\hline & $15 \mu \mathrm{m}$ & 15 & & $\begin{array}{c}81 \mathrm{VHN} \\
(0.5 \mathrm{~N})\end{array}$ & 199 & 182 & 1.8 & -- & \\
\hline \multirow{2}{*}{$\begin{array}{c}\text { AZ91D } \\
+ \\
\beta \mathrm{SiC}\end{array}$} & \multirow{2}{*}{$50 \mathrm{~nm}$} & 0 & \multirow{2}{*}{$\begin{array}{l}\text { Ultrasonic } \\
\text { assisted } \\
\text { casting }\end{array}$} & -- & 174 & 104 & 3.6 & -- & \multirow{2}{*}{ [30] } \\
\hline & & 0.5 & & -- & 124 & 216 & 6.6 & -- & \\
\hline \multirow{5}{*}{$\begin{array}{c}\text { AZ91D } \\
+ \\
\beta \mathrm{SiC}\end{array}$} & \multirow{5}{*}{$40 \mathrm{~nm}$} & 0 & \multirow{5}{*}{$\begin{array}{l}\text { Ultrasonic } \\
\text { assisted } \\
\text { casting }\end{array}$} & 63.5 & 133 & 65 & 2.2 & -- & \multirow{5}{*}[31,32]{} \\
\hline & & 0.5 & & 64.8 & 180 & 140 & 2.1 & -- & \\
\hline & & 1 & & 66.8 & 191 & 141 & 2.4 & -- & \\
\hline & & 1.5 & & 71.1 & 146 & 99 & 1.5 & -- & \\
\hline & & 2 & & 73.2 & 137 & 117 & 1.3 & -- & \\
\hline
\end{tabular}

\subsection{Alumina $\left(\mathrm{Al}_{2} \mathrm{O}_{3}\right)$}

Though the properties of AZ91/SiC composites are promising, they are found to be very brittle. So, $\mathrm{Al}_{2} \mathrm{O}_{3}$ is an another choice of reinforcement for the improved ductility with good tensile and compressive strength. These particles promote creep resistance as well [35]. However, limited works are identified with $\mathrm{Al}_{2} \mathrm{O}_{3 p}$ reinforced AZ91 composites fabricated through STIR casting in the recent years. Maher Mounib et al. [36] reported the reactivity of alumina in AZ91 Mg MMCs through the experiment carried out by melt stirring process coupled with an ultrasonic vibration.
Thermodynamic calculations and kinetics of these reactions indicated the formation of $\mathrm{MgO}$ and confirmed by EDS studies.

Yadav. S. D et al. [37] attempted hybrid processing method in which $\gamma$ - alumina nano particles are added to AZ91 molten metal and was stirred by ultrasonic processing. Hardness, tensile and tribological characteristics of these composites was investigated in support with optical micrographs and X-ray diffraction studies. Mahmoud, M. G et al. [38] used Semi-Solid Rheocasting (SSR) technique to prepare nano $\alpha-\mathrm{Al}_{2} \mathrm{O}_{3}$ of $\sim 80 \mathrm{~nm}$ reinforced AZ91 
composites in 1, 2, 3 and $4 \%$ weight fractions. The microstructural images have $\alpha$ and $\gamma$-phases along with an intermetallic compound $\mathrm{Mg}_{17} \mathrm{Al}_{12}$ (Fig. 4). $\gamma$-phase is a eutectic compound reported as a very key feature in altering the mechanical properties. For 2 wt. $\%$ $\mathrm{Al}_{2} \mathrm{O}_{3}$, the hardness was improved by $17 \%$ while $5 \%$ increase in wear resistance and 50\% in corrosion resistance was observed. Sameer Kumar et al. [39] also adopted semi solid stir casting procedure to fabricate nano $\mathrm{Al}_{2} \mathrm{O}_{3}$ reinforced $\mathrm{AZ91E}$ composites with an average particle size $50 \mathrm{~nm}$. The pre - heated particles are added to AZ91 melt at $590{ }^{\circ} \mathrm{c}$ and stirred with an automatic stirrer for $3-5$ minutes at $450 \mathrm{rpm}$. The effect of weight fractions on the density, porosity, hardness and tensile mechanical behavior was investigated. The composites with 2 wt.\% shown improved properties because of uniform distribution while the weight fraction beyond $2 \%$ caused agglomeration of particles and resulted in reduction of properties as confirmed by microstructural analysis.

Tara Sasanka et al. [40-41] reported that semi solid STIR cast based 2 wt.\% $\mathrm{Al}_{2} \mathrm{O}_{3} / \mathrm{AZ} 91 \mathrm{E}$ composites exhibited higher wear resistance because of hard ceramic particles and uniform distribution in composite. To promote good wettability between matrix and reinforcement, Sameer Kumar et al. [42] prepared surface modified ( $\mathrm{Ni}$ coated) nano alumina particles using electroless plating method and introduced in to AZ91E alloy. The mechanical response of the composites with coated and uncoated reinforcement is mentioned in Table 4. An overall improvement of 20-30\% hardness and tensile strength was observed in $2 \mathrm{wt} . \% \mathrm{Ni}$ coated alumina reinforced composites. The fracture studies of these composites reported a mixed mode of ductile and brittle failure. A significant improvement in fatigue and impact behaviors of 2 wt.\% $\mathrm{Ni}$ coated alumina reinforced composites has also been observed because of strong metal - metal bonding between matrix and reinforcement [ 43,44].
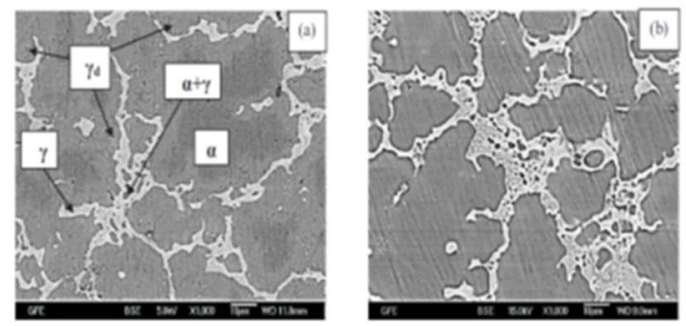

Fig. 4. SEM observation of: a) AZ91 alloy, b) AZ91 composite with 2 wt.\% $\mathrm{Al}_{2} \mathrm{O}_{3}$ reinforcement [38]

Tab. 4. Mechanical properties of Ni coated and Uncoated nano alumina in AZ91E composites as mentioned by Sameer Kumar et al [39, 42]

\begin{tabular}{lcclll}
\hline Un Coated alumina in AZ91E composites [39] & & & \\
\hline Wt. $\%$ & $\begin{array}{l}\text { Micro Hardness } \\
\text { VHN }\end{array}$ & $\begin{array}{c}\text { Young's Modulus } \\
\text { MPa }\end{array}$ & $\begin{array}{l}\text { Yield Stress } \\
\text { MPa }\end{array}$ & $\begin{array}{l}\text { Ultimate Tensile } \\
\text { Strength, MPa }\end{array}$ & $\begin{array}{l}\text { \% of } \\
\text { Elongation }\end{array}$ \\
\hline 0 & $64.94 \pm 2.64$ & 43454.15 & $96.61 \pm 4.07$ & $162.77 \pm 2.08$ & $3.08 \pm 0.27$ \\
\hline 1 & $72.11 \pm 1.86$ & 47033.92 & $122.54 \pm 2.84$ & $178.39 \pm 3.03$ & $2.92 \pm 0.34$ \\
\hline 1.5 & $73.61 \pm 2.57$ & 48489.00 & $138.36 \pm 3.60$ & $192.37 \pm 3.31$ & $2.83 \pm 0.29$ \\
\hline 2 & $77.61 \pm 3.08$ & 49913.55 & $146.21 \pm 3.11$ & $205.52 \pm 2.74$ & $2.65 \pm 0.31$ \\
\hline 2.5 & $75.45 \pm 3.81$ & 51292.24 & $148.17 \pm 3.94$ & $199.77 \pm 2.41$ & $2.31 \pm 0.21$ \\
\hline 3 & $73.77 \pm 2.99$ & 52194.14 & $150.95 \pm 4.02$ & $188.26 \pm 3.69$ & $1.94 \pm 0.26$ \\
\hline Ni Coated alumina in AZ91E composites [42] & & & \\
\hline 1 & $77.56 \pm 2.05$ & 48208.50 & $129.56 \pm 2.88$ & $191.97 \pm 2.83$ & $3.56 \pm 0.24$ \\
\hline 1.5 & $79.68 \pm 2.54$ & 49345.20 & $146.55 \pm 3.09$ & $207.07 \pm 3.01$ & $3.44 \pm 0.32$ \\
\hline 2 & $87.94 \pm 1.57$ & 51023.70 & $155.05 \pm 2.03$ & $221.09 \pm 2.03$ & $3.15 \pm 0.19$ \\
\hline 2.5 & $83.43 \pm 2.92$ & 52234.56 & $157.17 \pm 2.05$ & $215.45 \pm 3.23$ & $2.71 \pm 0.33$ \\
\hline 3 & $78.36 \pm 3.90$ & 53332.10 & $159.3 \pm 2.74$ & $203.03 \pm 4.18$ & $2.07 \pm 0.34$ \\
\hline
\end{tabular}




\subsection{Other particle reinforcements in AZ91}

In addition to Silicon Carbide (SiC) and Aluminum Oxide $\left(\mathrm{Al}_{2} \mathrm{O}_{3}\right)$, other ceramic particle reinforcements are also being used in the preparation of $\mathrm{Mg}$ MMCs in view of desired properties and application. $\mathrm{TiC}$ particles $\left(\mathrm{TiC}_{\mathrm{p}}\right)$ play a critical role in the damping characteristics of MMCs. In addition, reinforcing the $\mathrm{AZ}$ series alloys with $\mathrm{TiC}_{\mathrm{p}}$ greatly increase yield strength and tensile modulus while ductility is found to be slightly reduced [10]. Anil Kumar et al. [45] prepared AZ91/ TiCp composite with 3, 6, 9 and 12 weight percentages with a particle size of $\sim 20$ microns. Hardness, tensile and compressive strength of the composite was observed along with wear behavior. The yield and ultimate tensile strength of the composite was initially lower than AZ91 alloy, but it was increased on further addition of $\mathrm{TiC}$ reinforcement. This was reported as poor performance of the processing technique at lower percentage of reinforcement as it was not created a good interface between brittle TiC particle and large secondary phase. However, at higher reinforcement percentages grain refinement was occurred and resulted in improved properties. Calcium added AZ91C alloy i.e. AZX915 based 12 wt. $\%$ TiC $_{p}$ composites (particle size $5-20 \mu \mathrm{m}$ ) was prepared by Nagaraj M. Chelliah et al. [46]. The wear behavior of AZX915 and AZX915/TiC $p$ composites under heat treatment are compared and observed that the wear rate of as cast composite is reduced by 2 times than the composite with heat treatment because of intermetallic precipitates of $\beta-\mathrm{Mg}_{17} \mathrm{Al}_{12}$ and $\mathrm{Al}_{2} \mathrm{Ca}$ phases.

Boron Carbide $\left(\mathrm{B}_{4} \mathrm{C}\right)$ is known for high hardness, high modulus elasticity and fracture toughness with improved bond strength. M.E. Turan et al. [47] illustrated the wear behaviors of AZ91 with $50 \% \mathrm{SiC}_{\mathrm{p}}$ and $\mathrm{AZ} 91$ with $50 \% \mathrm{~B}_{4} \mathrm{C}_{\mathrm{p}}$ with an average particle size $45 \mu \mathrm{m}$. The hardness values of AZ91 with $50 \% \mathrm{SiCp}$

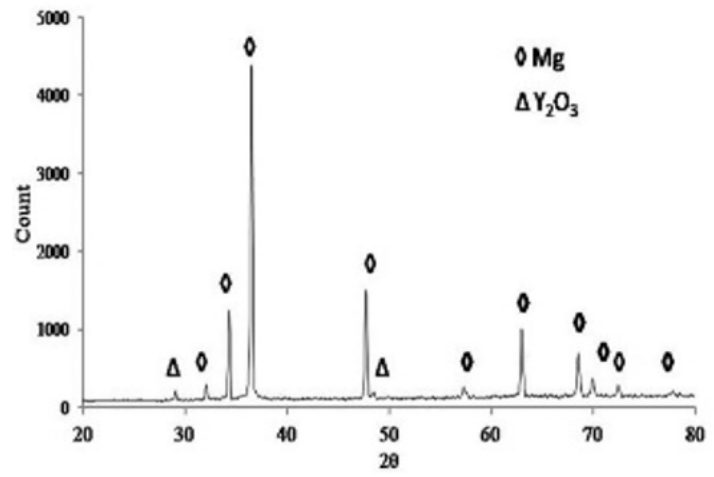

(a) are higher than the composites fabricated with AZ91 with $50 \% \quad \mathrm{~B}_{4} \mathrm{C}_{\mathrm{p}}$ because of strong bonding between $\mathrm{AZ} 91$ and $\mathrm{SiC}_{\mathrm{p}}$ as reported. Further it is observed that AZ91/SiC $\mathrm{P}_{\mathrm{p}}$ composites shown better wear resistance, wear depth and wear rate with increase in load Ponnappa et al. [48] developed $\mathrm{Mg} / \mathrm{Y}_{2} \mathrm{O}_{3 p}$ and AZ91D/ $/ \mathrm{Y}_{2} \mathrm{O}_{3 \mathrm{p}}$ composites with average particle size $5 \mu \mathrm{m}$ through two step STIR casting method in 5,10,15 and $20 \%$ weight fractions. The X- Ray diffraction studies clearly shown the presence of interfacial/intermetallic products of AZ91 along with $\mathrm{Y}_{2} \mathrm{O}_{3 \mathrm{p}}$ while only magnesium was observed in $\mathrm{Mg} / \mathrm{Y}_{2} \mathrm{O}_{3 \mathrm{p}}$ composites. (Fig. 5a - b). AZ91D/ $\mathrm{Y}_{2} \mathrm{O}_{3 \mathrm{p}}$ composites exhibited good improvement in hardness, elastic modulus and tensile strength because of precipitation hardening and grain refinement.

Katarzyna N. Braszczyńska Malik and Elżbieta Przełożyńska [49] fabricated and investigated the microstructure of AZ91 Mg MMC reinforced with $\mathrm{Ti}_{6} \mathrm{Al}_{4} \mathrm{~V}$ particles (30\% wt. fraction.) in as cast, solution treatment and T6 conditions. Apart from $\alpha-$ $\mathrm{Mg}$ phase, $\gamma$ eutectic phase has also been observed in as cast specimens. No new phases in the composite were observed due to the implementation of thermal treatments. Chun-Lei Zhang et al. [50] used a new liquid settling process for the preparation of TC4 (Ti6Al4V) particle reinforced AZ91 alloy with an average particle diameter of $100 \mu \mathrm{m}$ in a volume fraction nearly equal to $50 \%$. The methodology of this process in contrast to semi solid STIR casting, ultrasonic STIR casting is described in Figure 6. Apart from the former methods, the novel liquid settling process accommodated a high reinforcement percentage with uniform distribution. The ultimate tensile strength of the composites prepared through this process was improved by almost 30\% than semi solid casting process and $10 \%$ than STIR casting with ultrasonic setup.

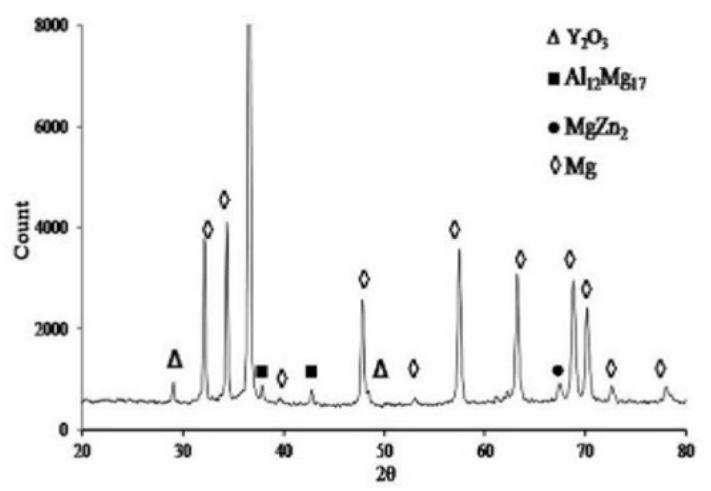

(b)

Fig. 5. XRD patterns of: a) $\mathrm{Mg} / \mathrm{Y}_{2} \mathrm{O}_{3 p}$ (b) $\mathrm{AZ} 91 \mathrm{D} / \mathrm{Y}_{2} \mathrm{O}_{3 p}$ composites 


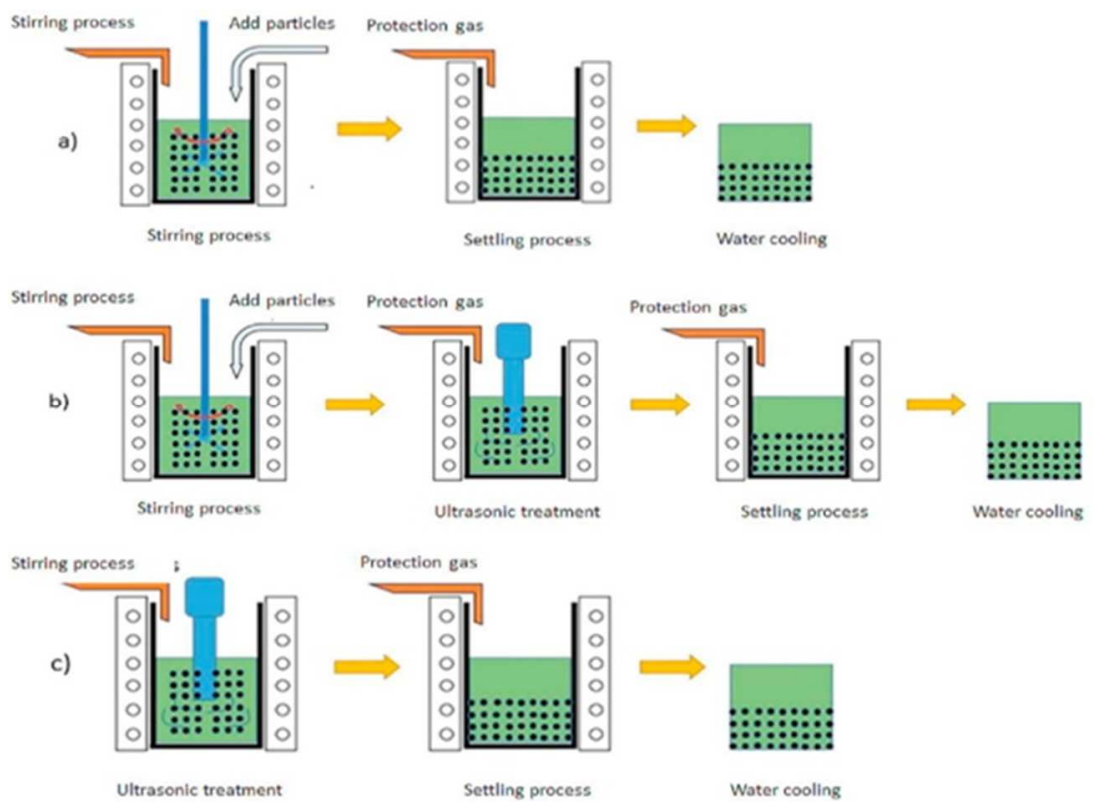

Fig. 6. Casting methods used by Chun-Lei Zhang et al.: a) semi solid method, b) ultrasonic method, c) liquid settling method [50]

Although a large number ceramic particles are available for reinforcement in AZ91 alloys, the selection of proper reinforcement and its interaction with matrix decide the performance of the composite. A good correlation between D.J. Lloyd [9] and published literature in Mg MMCs has been observed as most of the works are carried with $\mathrm{SiC}$ and $\mathrm{Al}_{2} \mathrm{O}_{3}$ particles because of good compatibility and capable of producing broad range physical and mechanical properties with low cost of fabrication.

\section{PARTICLE BASED AZ91 HYBRID COMPOSITES BY STIR CASTING}

Hybrid composites are the special purpose composites with more than one element as reinforcement. A few studies have also been carried out on AZ91 based hybrid composites to accommodate a large range of opportunities in aerospace and automotive sector. The advantage of hybrid metal matrix composites is combining various forms of reinforcement i.e. both particles and short fibres can also be employed. Qiang, Zhang [51] and E. Suneesh [52] stated the primary objectives in preparing the magnesium hybrid composites as (i) to optimize the performance of engineering materials (ii) to create a provision for mass production and (iii) to enhance the wettability. S. Ravi Kumar et al. [53] reviewed the feasibilities of AZ91 with $\mathrm{SiC}$ and Fly ash hybrid composites manufactured through STIR casting. E. Suneesh [52] et al. conducted a comprehensive review on Magnesium based hybrid composites in terms of processing methods, metallurgical behavior, and mechanical properties. Recent works carried by researchers in AZ91 based hybrid composites are listed in Table 5.
From the literature [54-61], the tensile strength, wear and creep resistance of the monolithic AZ91 alloys are observed to be significantly improved with adequate grain precision due to the addition of hybrid materials. it has also been evidenced that the ductile nature of brittle AZ91 alloys/composites is enhanced considerably. But the acceptance of these hybrid composites mainly relies on the careful handling of the reinforcement particles, strengthening mechanisms due to intermittent phases and interactions. Though the properties are encouraging, the research on magnesium based hybrid composites will become viable only with the development of economical processing methods.

\section{CONCLUSIONS AND FUTURE SCOPE}

This paper reviewed the recent literature carried in the fabrication of AZ91 magnesium alloy based particulate composites through STIR casting process during the last ten years to the best our knowledge. Most of the works are identified with AZ91D and AZ91E as a matrix material to gain the advantage of good mechanical behavior with improved corrosion resistance. $\mathrm{SiC}, \mathrm{Al}_{2} \mathrm{O}_{3}, \mathrm{TiC}, \mathrm{B}_{4} \mathrm{C}$ are the most common reinforced ceramic particles introduced into AZ91 alloy among which $\mathrm{SiC}$ and $\mathrm{Al}_{2} \mathrm{O}_{3}$ are the major choice by many researchers due to compatibility with AZ91. Size and weight fraction of the particles are also observed to be most significant parameters in achieving uniform distribution and grain refinement of Mg MMCs. The influence of these parameters on the physical, mechanical and tribological properties of the composites are presented and correlated with metallurgical investigations. 
Tab. 5. Recent works on AZ91 based hybrid composites fabricated via stir casting

\begin{tabular}{|c|c|c|c|c|c|c|}
\hline Author & Matrix & Reinforcements & Wt $\%$. & Particle size & Findings & Ref. \\
\hline \multirow{2}{*}{$\begin{array}{l}\text { Xia zhou } \\
\text { et al. }\end{array}$} & \multirow{2}{*}{ AZ91 } & $\mathrm{SiC}$ & 0.3 & $30 \mathrm{~nm}$ & \multirow{2}{*}{$\begin{array}{l}\text { Mechanical } \\
\text { Behavior }\end{array}$} & \multirow{2}{*}{54} \\
\hline & & $\mathrm{CNT}$ & 0.7 & $50 \mathrm{~nm}$ & & \\
\hline \multirow{2}{*}{$\begin{array}{l}\text { Mohammed Ali et } \\
\text { al. }\end{array}$} & \multirow{2}{*}{ AZ91 } & $\mathrm{SiC}$ & $1-3$ & -- & \multirow{2}{*}{ Wear Behavior } & \multirow{2}{*}{ [55] } \\
\hline & & $\mathrm{Al}_{2} \mathrm{O}_{3}$ & $3-1$ & -- & & \\
\hline \multirow{2}{*}{$\begin{array}{l}\text { B. M. Girish } \\
\text { et al. }\end{array}$} & \multirow{2}{*}{ AZ91 } & $\mathrm{SiC}$ & $1-3$ & $37-50 \mu \mathrm{m}$ & \multirow{2}{*}{ Wear Behavior } & \multirow{2}{*}[56]{} \\
\hline & & Graphite & $1-3$ & $37-50 \mu \mathrm{m}$ & & \\
\hline \multirow{2}{*}{$\begin{array}{l}\text { I. Aatthisugan } \\
\text { et al. }\end{array}$} & \multirow{2}{*}{ AZ91D } & Boron carbide $\left(\mathrm{B}_{4} \mathrm{C}\right)$ & $0,1.5$ & -- & \multirow{2}{*}{$\begin{array}{l}\text { Mechanical and } \\
\text { Wear Behavior }\end{array}$} & \multirow{2}{*}[57]{} \\
\hline & & Graphite & $1.5,0$ & -- & & \\
\hline \multirow{2}{*}{$\begin{array}{l}\text { N. Nafeed } \\
\text { et al. }\end{array}$} & \multirow{2}{*}{ AZ91E } & $\mathrm{SiC}$ & 5 & $50 \mu \mathrm{m}$ & \multirow{2}{*}{ Wear Behavior } & \multirow{2}{*}[58]{} \\
\hline & & Graphite & 10 & $50 \mu \mathrm{m}$ & & \\
\hline \multirow{2}{*}{$\begin{array}{l}\text { Shruti } \\
\text { et al. }\end{array}$} & \multirow{2}{*}{ AZ91 } & $\mathrm{SiC}$ & $15-25$ & $30 \mu \mathrm{m}$ & \multirow{2}{*}{$\begin{array}{l}\text { Mechanical and } \\
\text { Wear Behavior }\end{array}$} & \multirow{2}{*}{ [59] } \\
\hline & & $\mathrm{Al}_{2} \mathrm{O}_{3}$ & $5-20$ & -- & & \\
\hline \multirow{2}{*}{$\begin{array}{l}\text { Sadanand sarapure } \\
\text { et al. }\end{array}$} & \multirow{2}{*}{ AZ91 } & $\mathrm{SiC}$ & $0-3$ & $27 \mu \mathrm{m}$ & \multirow{2}{*}{$\begin{array}{l}\text { Mechanical } \\
\text { Behavior }\end{array}$} & \multirow{2}{*}[60]{} \\
\hline & & Graphite & $0-3$ & $27 \mu \mathrm{m}$ & & \\
\hline $\begin{array}{l}\text { S. Jayabharathy et } \\
\text { al. }\end{array}$ & AZ91 & $\mathrm{TiO}_{2}$ & $1-2$ & -- & $\begin{array}{l}\text { Mechanical and } \\
\text { Wear behavior }\end{array}$ & [61] \\
\hline
\end{tabular}

Though particle reinforced composites shown superior properties, the studies on chemical reactions and interfacial characteristics are reported only by few researchers. The interfacial studies to be much more analyzed to understand the nature of the composite. STIR casting technique is found to be the most common practice in manufacturing of $\mathrm{Mg}$ MMCs but the homogeneous distribution and maintain good interface strength is the major challenge. Some works are reported with process innovations such as semi solid STIR casting, ultrasonic vibration assisted STIR casting and liquid settling methods in the preparation of AZ91 composites. However, the application of these methods in commercial products has to be reported. The future directions of current investigation may include newer particle reinforcements, simulation studies for understanding matrix - particle interactions, wettability enhancement methods, development of energy efficient casting procedures...etc. to produce high quality particle reinforced AZ91 Mg MMCs for the sustainable green growth.

Conflict of Interest: the author(s) expressed no conflict of interest.

\section{Nomenclature}

Symbols

$\alpha, \beta, \gamma$ of $M g \quad-\quad$ Different phases of Magnesium alloys Subscript ' $p$ ' - Particle Reinforcement

T6 _ $\quad-\quad$ Heat Treatment Procedure

Acronyms

$\mathrm{Mg} \quad$ - Magnesium

Mg MMC _ $\quad$ Magnesium Metal Matrix Composites

Al $\quad-\quad$ Aluminum

Zn $\quad-\quad$ Zinc

Mn _ - Manganese

$\mathrm{Cu} \quad-\quad$ Copper

$\mathrm{Fe} \quad-\quad$ Iron

Ni $\quad-\quad$ Nickel

$\mathrm{Si} \quad-\quad$ Silicon

AZ _ - Magnesium - Aluminum - Zinc Alloys

AZ91 - $\quad$ Mg $90 \%, \mathrm{Al} 9 \%, \mathrm{Zn} 1 \%$ alloy

AZ91 A-E - AZ91 alloys

$\mathrm{Mg}_{17} \mathrm{Al}_{12} \quad$ - $\quad$ Intermetallic Compound of Mg-Al-Zn

Alloy

UTS _ - Ultimate Tensile Strength

YTS _ - Yield Tensile Strength

UCS - - Ultimate Compressive Strength

IRP $\quad-\quad$ Interfacial Reaction Products

BN $\quad-\quad$ Boron Nitride

AlN _ $\quad$ Aluminum Nitride

$\mathrm{SiC} \quad$ - $\quad$ Silicon Carbide 


$\begin{array}{lll}\mathrm{Al}_{2} \mathrm{O}_{3} & - & \text { Alumina } \\ \mathrm{Y}_{2} \mathrm{O}_{3} & - & \text { Yttrium Oxide } \\ \mathrm{TC} 4 & - & \text { A titanium alloy with Ti6Al4V } \\ & & \text { combination } \\ \mathrm{TiO}_{2} & - & \text { Titanium Dioxide } \\ \mathrm{TiC} & - & \text { Titanium Carbide } \\ \mathrm{B}_{4} \mathrm{C} & - & \text { Boron Carbide } \\ \mathrm{CNT} & - & \text { Carbon Nano Tubes } \\ \mathrm{XRD} & - & \text { X- Ray Diffraction } \\ \text { SEM } & - & \text { Scanning Electron Microscope }\end{array}$

\section{References}

1. A.A. Luo. (2002). Magnesium: Current and potential automotive applications, JOM, Vol 54, Issue 2, pp: 4248, 2002. https://doi.org/10.1007/BF02701073

2. Mustafa Kemal Kulekci. (2008). Magnesium and its alloys applications in automotive industry, Internationa Journal of Advanced Manufacturing Technology, Vol. 39, Issue 9-10, pp: 851-865. https://doi.org/10.1007/ s00170-007-1279-2

3. D. Sameer Kumar, C. Tara Sasanka, K. Ravindra, K.N.S Suman. (2015). Magnesium and Its Alloys in Automotive Applications - A Review, American Journal of Materials Science and Technology, Vol.4, No.1, pp. 12-30. http://dx.doi.org/10.7726/ajmst. 2015.1002

4. M.M. Avedesian, H. Baker. (1999). Magnesium \& Magnesium Alloys, ASM Specialty Handbook, ASM International. USA.

5. M. Gupta, N.M.L. Sharon. (2011). Magnesium, Magnesium Alloys, and Magnesium Composites. John Wiley \& Sons , USA.

6. D. Sameer Kumar, C. Tara sasanka. (2017). Magnesium and its Alloys for Automotive in Lightweight and Sustainable Materials for Automotive Applications Published by CRC Press (Taylor \& Francis Group), USA. pp: 329-368, 2017. ISBN 9781498756877.

7. Horst E. Friedrich, Barry L.Mordike. (2006). Magnesium Technology: Metallurgy, Design Data, Applications Springer-Verlag Berlin Heidelberg, New York. ISBN-13 978-3-540-20599-9.

8. P.K. Mallick. (20100. Materials, Design and Manufacturing for Lightweight Vehicles, CRC Press, USA.

9. D.J. Lloyd. (1994), Particle reinforced Aluminum and Magnesium Matrix Composites, Int. Mater. Rev., Vol 39 (1), pp: 1-23. https://doi.org/10.1179/imr.1994.39.1.1

10. Abhijit Dey and Krishna Murari Pandey. (2015). Magnesium Metal Matrix Composites - A Review, Rev. Adv. Mater. Sci. 42 , pp: 58-67.

11. Ye H Z and Liu X Y. (2004). Review of recent studies in magnesium matrix composites. Journal of Materials Science , 39, 6153-6171. https://doi.org/10.1023/ B:JMSC.0000043583.47148.31.

12. Guohong Ma, Hao Xiao, Jia Ye \& Yinshui He. (2020). Research status and development of magnesium matrix composites. Materials Science and Technology. https://doi.org/10.1080/02670836.2020.1732610

13. Amandeep Singh, Niraj Bala. (2017). Evaluation Of Microstructural And Mechanical Behavior of Some Magnesium Metal Matrix Composites. Advanced Materials Manufacturing \& Characterization, 7(2), pp:38-43. http://dx.doi.org/10.11127/ijammc2017.10.01

14. D. Dash, S. Samanta, R. N. Rai. (2018). Study on Fabrication of Magnesium based Metal Matrix Composites and its improvement in Mechanical and Tribological Properties- A Review, IOP Conf. Series: Materials Science and Engineering , $377,012133$. https://doi.org/10.1088/1757-899X/377/1/012133

15. Hajo Dieringa. (2018). Processing of Magnesium-Based Metal Matrix Nanocomposites by Ultrasound-Assisted
Particle Dispersion : A Review , Metals , 8 ,431 ,https://doi.org/10.3390/met8060431

16. Information from http://mg.tripod.com/asm_prop.htm accessed on 02.04.2020

17. Charles Moosbrugger. (2017). Engineering properties of magnesium alloys, ASM International, USA. EISBN : 978-1-62708-144-2

18. Bruce Gwynne., \& Paul Lyon. (2007). Magnesium Alloys in Aerospace Applications, Past Concerns, Current Solutions, Triennial International Aircraft Fire \& Cabin Safety Research Conference, October 29 November 1, 2007. http://www.fire.tc.faa.gov/2007 conference/files/Materials_Fire_Safety/WedAM/Gwynn eMagnesium/GwynneMagnesiumPres.pdf

19. Murugan, Srinivasan \& Nguyen, Bau \& Gupta, Manoj. (2019). Synthesis of Magnesium Based Nanocomposites, Magnesium - The Wonder Element for Engineering/Biomedical Applications, Intech Open. http://dx.doi.org/10.5772/intechopen.84189

20. J. Hashim, L. Looney, M.S.J. Hashmi. (1999). Metal matrix composites: production by the stir casting method, Journal of Materials Processing Technology, Vol 92 -93, pp: 1-7, 1999. https://doi.org/10.1016/ S0924-0136(99)00118-1

21. Poddar P, Srivastava VC, De PK, et al. (2007) Processing and mechanical properties of $\mathrm{SiC}$ reinforced cast magnesium matrix composites by stir casting process. Mater Sci Eng A. , 460-461:357-364. https://doi.org/10.1016/j.msea.2007.01.052

22. X. J. Wang et al. (2009). The interfacial characteristic of SiCp/AZ91 magnesium matrix composites fabricated by stir casting, J Mater Sci , 44 ,2759-2764. https://doi.org/10.1007/s10853-009-3360-8

23. Kandil. (2012) .Microstructure And Mechanical Properties Of SiCp/AZ91 Magnesium Matrix Composites Processed By Stir Casting. Journal of Engineering Sciences, Assiut University, Vol. 40, No 1, pp. $255-270$.

24. Sujayakumar Prasanth et al. (2012). Microstructure and Properties of Stir Cast AZ91 Mg Alloy - SiCp Composites, Materials Science Forum, Vol. 710, pp 365-370.

25. https://doi.org/10.4028/www.scientific.net/MSF.710.365

26. Prasanth SUJAYAKUMAR et al. (2013). Sliding Wear Behavior of Stir Cast AZ91/ SiCp Composites. Journal of Solid Mechanics and Materials Engineering , Vol. 7, No. 2, 169- 175. https://doi.org/10.1299/jmmp.7.169

27. K. K. Ajith Kumar, Abhilash Viswanath, T. P. D. Rajan , U. T. S. Pillai , B. C. Pai. (2014). Physical, Mechanical, and Tribological Attributes of Stir-Cast AZ91/SiCp Composite , Acta Metall. Sin. (Engl. Lett.), 27(2), 295305. https://doi.org/10.1007/s40195-014-0045-3

28. Abhilash Viswanath et al. (2015). Investigation on mechanical properties and creep behavior of stir cast AZ91-SiCp composites, Journal of Magnesium and Alloys , Volume 3, Issue 1, Pages 16-22. https://doi.org/10.1016/j.jma.2015.01.001

29. P. Poddar, S. Mukherjee, and K.L. Sahoo. (2009). The Microstructure and Mechanical Properties of $\mathrm{SiC}$ Reinforced Magnesium Based Composites by Rheocasting Process, Journal of Materials Engineering and Performance, Vol. 18, pp:849-855. https://doi.org/10.1007/s11665-008-9334-1

30. S. Aravindan et al. (2015). Evaluation of physical and mechanical properties of AZ91D/SiC composites by two step stir casting process, Journal of Magnesium and Alloys, Vol 3, pp: 52-62. https://doi.org/10.1016/ j.jma.2014.12.008

31. WANG Zhao-hui et al. (2010). SiC nanoparticles reinforced magnesium matrix composites fabricated by ultrasonic method, Trans. Nonferrous Met. Soc. China , 
20 , s1029-s1032. https://doi.org/10.1016/S10036326(10)60625-5

32. X. Y. Jia et al. (2009). Magnesium matrix nanocomposites fabricated by ultrasonic assisted casting. International Journal of Cast Metals Research, Volume 22, Issue 1-4. 196-199. https://doi.org/10.1179/ $136404609 \times 367704$

33. Liu Shiying et al. (2009). Mechanical Properties and Microstrutures of Nano-Sized SiC Particles Reinforced AZ91D Nanocomposites Fabricated by High Intensity Ultrasonic Assisted Casting. Materials Science Forum Vols. 618-619 , pp 449-452. https://doi.org/10.4028/ www.scientific.net/MSF.618-619.449

34. Anil Kumar, Santosh Kumar, N. K. Mukhopadhyay. (2018). Introduction to magnesium alloy processing technology and development of low-cost stir casting process for magnesium alloy and its composites. Journal of Magnesium and Alloys , Volume 6, Issue 3, Pages 245-254. https://doi.org/10.1016/j.jma.2018.05.006

35. Asgari A, Sedighi M, Krajnik P. (2019). Magnesium alloy silicon carbide composite fabrication using chips waste. J Clean Prod. , 232 , 1187-1194. https://doi.org/10.1016/j.jclepro.2019.06.018

36. M. Paramsothy, J. Chan, R. Kwok, M. Gupta. (2012). $\mathrm{Al}_{2} \mathrm{O}_{3}$ nanoparticle addition to commercial magnesium alloys: multiple beneficial Effects. Nanomaterials,2,147162. https://doi.org/10.3390/nano2020147

37. Maher Mounib et al. (2014). Reactivity and Microstructure of $\mathrm{Al}_{2} \mathrm{O}_{3}$-Reinforced Magnesium-Matrix Composites. Advances in Materials Science and Engineering, Volume 2014, Article ID 476079, 6 pages. http://dx.doi.org/10.1155/2014/476079

38. Yadav, S. D., Bhingole, P. P., Chaudhari, G. P., Nath, S K., \& Sommitsch, C. (2015) . Hybrid Processing of AZ91 Magnesium Alloy/Nano- $\mathrm{Al}_{2} \mathrm{O}_{3}$ Composites. Key Engineering Materials, 651-653, 783-788 https://doi.org/10.4028/www.scientific.net/KEM.651653.783

39. Mahmoud, M. G et al (2014). Effect Of NanoReinforcement On Properties Of Cast Mg-Al Alloy Az91 , Magnesium Technology 2014 Edited by: Martyn Alderman, Michele V. Manuel, Norbert Hort, and Neale R. Neelameggham TMS (The Minerals, Metals \& Materials Society), PP:471 - 475.

40. Sameer Kumar D., K.N.S. Suman, et al. (2017) Microstructure, mechanical response and fractography of $\mathrm{AZ} 91 \mathrm{E} / \mathrm{Al}_{2} \mathrm{O}_{3}$ (p) nano composite fabricated by semi solid stir casting method, Journal of Magnesium and Alloys, Volume 5, Issue 1,Pages 48-55. https://dx.doi.org/10.1016/j.jma.2016.11.006

41. Tarasasanka C. Ravindra K. (2017). Application of Taguchi techniques to study dry sliding wear behaviour of magnesium matrix composites reinforced with alumina nanoparticles. Journal of Engineering Science and Technology , Vol. 12, No. 11, 2855-2865.

42. C. Tarasasanka , K. Snehita, K. Ravindra, D. Sameer Kumar. (2019). Optimization of dry sliding wear properties ofAZ91E/ nano $\mathrm{Al}_{2} \mathrm{O}_{3}$ reinforced metal matrix composite with grey relational analysis, International Journal of Engineering, Science and Technology, Vol. 11, No. 4, pp. 41-48. http://dx.doi.org/10.4314/ ijest.v11i4.4

43. Sameer Kumar D, K.N.S. Suman and Palash Poddar (2017). Effect of particle morphology of $\mathrm{Ni}$ on the mechanical behavior of AZ91E-Ni coated nano $\mathrm{Al}_{2} \mathrm{O}_{3}$ composites. Material Research Express,4,066505. https://doi.org/10.1088/2053-1591/aa6fe4

44. Devarakonda SK, Koka NSS. (2018). Estimation of high cycle fatigue life of AZ91E-Ni coated $\mathrm{Al}_{2} \mathrm{O}_{3}$ particulate nanocomposites using reliability based approach. J Inst
Eng (India) Series D. , 99 , 201-208. https://doi.org/10.1007/s40033-018-0164-5

45. D. Sameer Kumar, K. N. S. Suman \& Palash Poddar. (2020). A study on the impact and fatigue failure of AZ91E-Ni coated alumina composites, Canadian Metallurgical https://doi.org/10.1080/00084433.2020.1741913

46. Anil Kumar et al. (2018). Casting and Characterization of Tic Particulate Reinforced AZ91 Magnesium Alloy Metal Matrix Composite Through Stir Casting Process. International Journal of Mechanical Engineering and Technology (IJMET), Volume 9, Issue 6, pp. 856-863.

47. Nagaraj M. Chelliah, Harpreet Singh , M.K.Surappa. (2016). Correlation between microstructure and wear behavior of AZX915 Mg-alloy reinforced with $12 \mathrm{wt} \%$ TiC particles by stir-casting process, Journal of Magnesium and Alloys, Volume 4, Issue 4, Pages 306313. https://doi.org/10.1016/j.jma.2016.09.002

48. M.E. Turan et al. (2016). Wear behaviours of SiC and $\mathrm{B}_{4} \mathrm{C}$ particle reinforced AZ91 Magnesium matrix metal composites, World Academy of Science, Engineering and Technology - International Journal of Materials and Metallurgical Engineering, Vol:10, No:9, 1224-1227. https://doi.org/10.5281/zenodo.1126900

49. K Ponappa, S Aravindan and P Venkateswara Rao. (2012). Influence of $\mathrm{Y}_{2} \mathrm{O}_{3}$ particles on mechanical properties of magnesium and magnesium alloy (AZ91D). Journal of Composite Materials, 47(10), 1231-1239. https://doi.org/10.1177\%2F0021998312446501

50. Katarzyna N. Braszczyńska-Malik and Elżbieta Przełożyńska. (2014) . Microstructure Of AZ91-Ti6A14V Metal-Metal Composite In As-Cast Conditions And After Heat Treatment. Composites theory and practice , 14: $4,224-228$.

51. Zhang, C.-L., Wang, X.-J., Wang, X.-M., Hu, X.-S., \& $\mathrm{Wu}, \quad$ K. (2016). Fabrication, microstructure and mechanical properties of $\mathrm{Mg}$ matrix composites reinforced by high volume fraction of sphere $\mathrm{TC}_{4}$ particles. Journal of Magnesium and Alloys, 4(4), 286294. https://doi.org/10.1016/j.jma.2016.10.003

52. Qiang, Zhang. (2010). Development of Hybrid Mg-based Composites, Electronic Theses and Dissertations. 204. https://scholar.uwindsor.ca/etd/204.

53. E. Suneesh and M. Sivapragash. (2018). Comprehensive studies on processing and characterization of hybrid magnesium composites. Materials and Manufacturing Processes. https://doi.org/10.1080/10426914.2018.1453155

54. Ravi Kumar Saranu, Ratnam Chanamala, SrinivasaRao Putti. (2020). Processing, micro structures and mechanical properties of AZ91E, SiC and fly ash composites: A review. Materials Today: Proceedings, Available online 13 March 2020. https://doi.org/ 10.1016/j.matpr.2020.02.555

55. Xia Zhou et al. (2012). Tensile Mechanical Properties And Strengthening Mechanism Of Hybrid Carbon Nanotube And Silicon Carbide Nanoparticle-Reinforced Magnesium Alloy Composites. Journal of Nanomaterials , Volume 2012, Article ID 851862, 7 pages. https://doi.org/10.1155/2012/851862

56. Mohammed Ali , R.M. Lathe. (2014). Wear Behavior of Mg Alloy Reinforced With Aluminum Oxide andSilicon Carbide Particulates. IJSRD - International Journal for Scientific Research \& Development, Vol. 2, Issue 07, pp: 203- 208.

57. B. M. Girish, B. M. Satish, Sadanand Sarapure, D. R. Somashekar and Basawaraj. (2015). Wear Behavior Of Magnesium Alloy AZ91 Hybrid Composite Materials. Tribology Transactions, 58:3, 481-489. https://doi.org/10.1080/10402004.2014.987858 
58. Aatthisugan, A. Razal Rose, D. Selwyn Jebadurai. (2017). Mechanical and wear behaviour of AZ91D magnesium matrix hybrid composite reinforced with boron carbide and graphite. Journal of Magnesium and Alloys , Volume 5, Issue 1, Pages 20-25. https://doi.org/10.1016/j.jma.2016.12.004

59. N. Nafeed et al. (2018). Evaluation Of Mechanical Properties Of $\mathrm{Mg}$ Alloy/Sic/Graphite Hybrid Metal Matrix Composites Using Desirability Approach. International Journal of Pure and Applied Mathematics, Volume 119 No. 12, 15619-15627.

60. Shruti, Babu Reddy, Ambadas. (2018). Fabrication And Characterization Of Mechanical And Tribological Properties Of Sic/Al2O3/AZ91 Magnesium Based Composite Material. Journal of Emerging Technologies and Innovative Research (JETIR), Volume 5, Issue 1 , pp: 43-49.

61. Sadanand Sarapure et al. (2018). Microstructure And Mechanical Behavior Of Magnesium Alloy AZ91 Hybrid Composites. IOP Conf. Series: Materials Science and Engineering, 310, 012161. https://doi.org/10.1088/ 1757-899X/310/1/012161

62. S. Jayabharathy, P.Mathiazhagan. (2019). Investigation of mechanical and wear behaviour of AZ91 magnesium matrix hybrid composite with $\mathrm{TiO}_{2} /$ graphene. Materials Today: Proceedings , Available online 24 October 2019. https://doi.org/10.1016/j.matpr.2019.09.142

\section{Biographical notes}

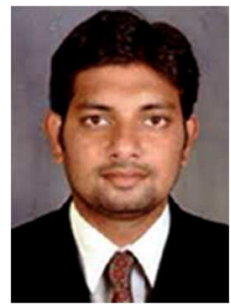

Anil Kumar Matta received his B.Tech. degree in Mechanical Engineering and M.E. degree from Andhra University College of Engineering, Visakhapatnam. Currently, he is a research scholar in the Department of Mechanical Engineering, Andhra University, Visakhapatnam and doing research on the development of newer materials for automotive applications.

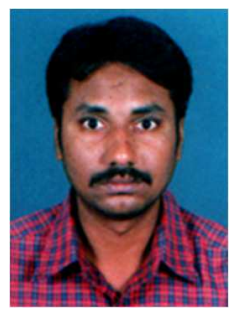

Naga Sai Suman Koka received his Ph.D. in 2006. He received 'Best Thesis' award for his research in that year from Andhra University, Visakhapatnam. He published good number of quality papers of National and International eminence. He was also the recipient of $R \& D$ projects from the prestigious scientific bodies in INDIA. His areas of interest include development of natural composites, analysis and their applications in Mechanical Engineering.

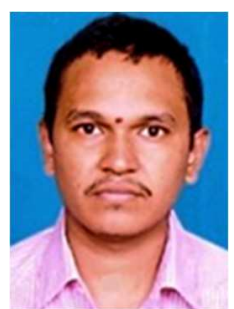

Sameer Kumar Devarakonda received both B.Tech. and M.Tech. degrees from Acharya Nagarjuna University, Guntur. He obtained Doctor of Philosophy from Andhra University, Visakhapatnam. At present, he is working in the Department of Mechanical Engineering, Bapatla Engineering College, Bapatla, His scientific interest includes composite materials and surface coatings. 